\title{
RECORDING OF TWO SPECIES OF THE GENUS DIPARTIELLA (RAABE, 1959) STEIN, 1961 (CLIOPHORA: TRICHODINIDAE) FOR THE FIRST TIME IN IRAQ FROM GILLS OF THE COMMON CARP CYPRINUS CARPIO
}

\author{
Kefah Naser Abdul-Ameer and Fatima Khalaf Atwan \\ Department of Biology, College of Education for Pure Science \\ (Ibn Al-Haitham), University of Baghdad, Baghdad, Iraq \\ E-mail: kefahnaser59@yahoo.com
}

Received Date: 23 April 2018

Accepted Date: 21 May 2018

\begin{abstract}
The examination of gills of the common carp Cyprinus carpio revealed the presence of two species of the family Trichodinidae belonging to the genus Dipartiella (Raabe, 1959) Stein, 1961 namely D. indiana Saha and Bandyopadhyay, 2017 and D. kazubski Mitra and Bandyopadhyay, 2009 for the first time in Iraq from Al-Graiat location on the Tigris River at Baghdad city. This also represents the first record of the genus Dipartiella from fishes of Iraq. The descriptions and measurements of these two parasite species as well as their illustrations were given.
\end{abstract}

Key words: Dipartiella, Dipartiella kazubski, Dipartiella indiana, Trichodinids, Tigris River, Iraq.

\section{INTRODUCTION}

Trichodinid ciliophorans are among the greatest common and mostly spread groups of symbionts as parasites of aquatic invertebrate and vertebrate hosts (Van As and Basson, 1989). The ciliates of Trichodinidae are characterized by proteinaceous cytoskeleton of the adhesive disc which consists of a ring of hollow conical elements, known as denticles, which although solid, consist of three distinct regions: a distal blade, a central part and a proximal ray. The denticles are inserted into each other subtended by a ring of fine skeletal rods, called radial pins. The disc is encircled by a moveable border membrane, reinforced by fine skeletal rays appearing as fine striations. The locomotory organelle consists of a compound wreath of oblique ciliary rows (Basson and Van As, 2006; El-Tantawy and El-Sherbiny, 2010). The morphology of the denticles in the adhesive disc has been widely used in species identification of trichodinids (Van As and Basson 1989, 1992). More than 300 trichodinid ciliophoran species, representing 11 genera have been reported from the gills, skin, fins, urinary bladder as well as reproductive system of different fish species in the world (Asmat, 2014; Özer et al., 2015). Among the genera of Trichodinidae the genus Dipartiella (Raabe, 1959) Stein, 1961. Species of this genus are described by denticle ring composed of tightly packed denticles, consisting only of blades and weakly developed central parts which do not extend into conical protrusions (Basson and Van As, 1989). According to the characteristic values of the denticles, Dipartiella was confirmed to be the most primitive genus in the existing genera of Trichodinidae (Gong et al., 2005). Only four species of this genus have 
been described throughout the world (Raabe, 1959; Mitra and Bandyopadhyay, 2009; Saha and Bandyopadhyay, 2017).

As no previous record was given for any species of the genus Dipartiella from fishes of Iraq (Mhaisen, 2018), the present study is concerned with the first record of this genus in Iraq, as it is found to be represented with two species (D. indiana and D. kazubski) parasitizing gills of Cyprinus carpio from Al-Graiat location in the Tigris river at Baghdad city.

\section{MATERIALS AND METHODS}

Fishes were collected weekly from Tigris river in Baghdad city near Al-Graiat location $\left(33^{\circ}\right.$ $24^{\prime} \mathrm{N}, 44^{\circ} 20^{\prime} \mathrm{E}$ ), between July 2015 and March 2016. A total of 42 specimens of C. carpio were examined. Skin and abstracted gills from fresh fishes were examined under a dissecting microscope. Fresh skin and gill smears, which made from the hosts, were microscopically examined for the presence of trichodinids. Smears with trichodinids were air-dried, fixed with absolute methanol and stained with Giemsa stain in accordance with the method proposed by Shuaib and Osman (2015).

The systematic descriptions used in the present study were based on the observations of living as well as Giemsa stained specimens; method of measurements and the terminology were mainly made according to Basson and Van As (1989). Drawings were done by using a camera Lucida. All measurements used in the description are presented in micrometers in the following order; minimum-maximum (mean) values. By contact on the email, the information on the previous account records of trichodinids of fishes of Iraq were checked wih the indexcatalogue of parasites and disease agents of fishes of Iraq (Mhaisen,2018).

\section{RESULTS AND DISCUSSION}

Two species of the genus Dipartiella namely $D$. indiana and $D$. kazubski were found on the gills of the common carp C. carpio from Al-Graiat location on the Tigris river at Baghdad city. The following is a brief account on their description and measurements.

\section{Dipartiella indiana Saha and Bandyopadhyay, 2017}

This parasite was obtained from gills of $C$. carpio with a prevalence of $2.4 \%$ and a mean intensity of 3. The following is an account on the description and measurements (in $\mu \mathrm{m}$, based on five specimens) of this parasite as shown in plate (1).

Small trichodinid, measures 29.6-31.2 (30.4) in diameter. Adhesive disc usually rounded 22.6-23.8 (23.2) in diameter which is encircled by finely striated border membrane 1.6-2.2 (1.9) wide. Number of radial pins per denticle 3-4. Diameter of denticle ring: 10.4-11.8 (11.1). Number of denticles 21. Span of denticle 3.4-4.2 (3.8). Macronucleus U-shaped, external diameter 22.6-24.2 (23.4), length of area between ends of macronucleus 3.5-3.9 (3.7). Micronucleus could not be noticed in any of the studied specimens.

Adhesive disc appeared uniformly blade elongated, anterior and posterior margins parallel, slightly curved towards $y+1$ axis, occupying most area between $y$-axes, distal margin extremely flat and truncated, runs parallel to the wide border membrane; tangent point blunt with rectangular end; central part reduced, ray absent. 
Kefah Naser Abdul-Ameer \& Fatima Khalaf Atwan

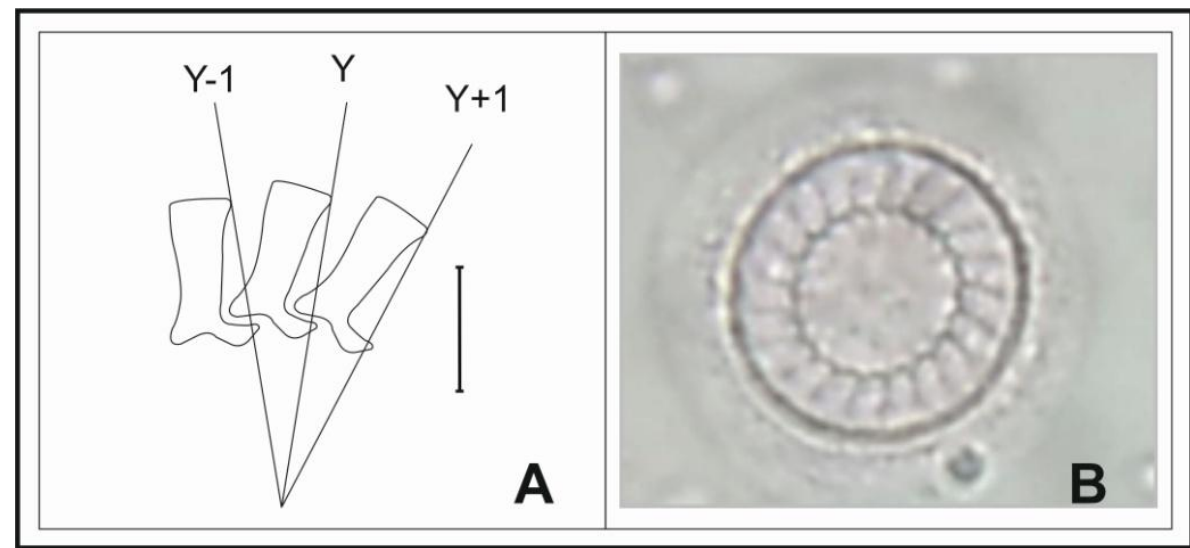

Plate 1: Dipartiella indiana. Diagrammatic drawing. (Scale bar $=3.2 \mu \mathrm{m}$ ),

B- Photomicrograph (1000x).

The description and measurements of the present $D$. indiana is in agreement with those reported by Saha and Bandyopadhyay (2017) from gills of Carassius auratus from fish farms of West Bengal, India.

\section{Dipartiella kazubski Mitra and Bandyopadhyay, 2009}

This parasite was obtained from gills of $C$. carpio with a prevalence of $7.1 \%$ and a mean intensity 2 . The following is an account on the description and measurements (in $\mu \mathrm{m}$, based on five specimens) of this parasite as shown in plate (2).

Small trichodinid, 18.2-19.8 (19.0) in diameter; adhesive disc usually rounded 14.2-15.2 (14.7) in diameter which is encircled by finely striated border membrane 1.0-1.6 (1.3) wide; number of radial pins per denticle 4. Diameter of denticle ring: 9.6-10.0 (9.8); number of denticles 33, span length of denticle: 3.2-3.8 (3.5).

Macronucleus C-shaped, external diameter 13.4-13.8 (13.6), length of area between ends of macronucleus 2.0-2.4 (2.2). Micronucleus could not be noticed in any of the studied specimens.

Adhesive disc mostly appeared oblong. Blade broad, rectangular, anterior and posterior straight and parallel, slightly curved towards $\mathrm{Y}+1$ axis, occupies most area between y-axis, distal margin of blade truncated, remains in close proximity to border membrane and runs parallel with it. Tangent point commonly like a point. Anterior blade margin do not touches or extends beyond $\mathrm{Y}+1$ axis. Posterior margin of blade almost straight. Central part reduced, ray absent. 
Recording of two species of the genus Dipartiella

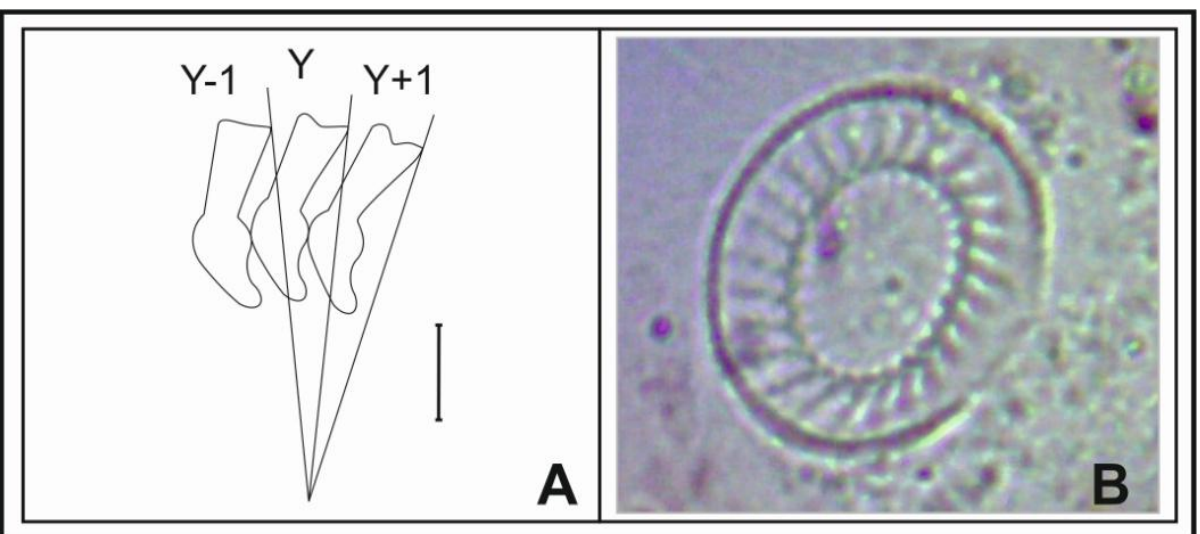

Plate 2: Dipartiella kazubski. A-Diagrammatic drawing. (Scale bar $=1.2 \mu \mathrm{m}$ ),

B- Photomicrograph (1000x).

The descriptions and measurements of the present $D$. kazubski are in agreement with those reported by Mitra and Bandyopadhyay (2009) from gills of both Batasio batasio and Wallago attu of the river Tista and the river Churni, respectively, of West Bengal, India.

According to Mhaisen (2018), the occurrence of the two parasites of the present study, Dipartiella indiana and D. kazubski represents their first record in fishes of Iraq as no previous record was given for these parasites from fishes of Iraq.

\section{ACKNOWLEDGEMENTS}

Thanks are due to Prof. Dr. Furhan T. Mhaisen for permission to use his index-catalogue of parasites and disease agents of fishes of Iraq and his critical reading of the manuscript. Thanks due to Rana S. Shellal, Department of Biology, College of Education for Pure Science (Ibn Al-Haitham) for providing some of the references of this study.

\section{LITERATURE CITED}

Asmat, G. S. M. 2014. Record of Trichodina gobii Raabe, 1959 (Ciliophora: Trichodinidae) from Dusky sleeper, Eleotris fuska (Forster, 1801) (Perciformes: Eleotridae) in West Bangal, India. Bonneprani-Bangladish Wildife Bulletin, 7(2): 1-6.

Basson, L. and Van As, J. G. 1989. Differential diagnosis of the genera in the family Trichodinidae (Ciliophora: Peritrichida) with the description of a new genus ectoparasitic on freshwater fish from southern Africa. Systematic Parasitology, 13: 153-160.

Basson, L. and Van As, J. G. 2006. Trichodinidae and other ciliophorans (Phylum Ciliophora): 154-182. In: Fish Diseases and Disorders, 2nd Edn, Vol. I, Protozoan and Metazoan Infections (ed. Woo, P.T.K.), CABI, Wallingford, UK, 791pp.

El-Tantawy, S. A. M and El-Sherbiny, H. A. E. 2010. Ectoparasitic trichodinians infecting catfish Clarias gariepinus inhabiting Nile Delta water of the River Nile, Dakahlia Province, Egypt. Journal of American Science, 6(9): 656-668. 
Kefah Naser Abdul-Ameer \& Fatima Khalaf Atwan

Gong, Y., Yu, Y., Feng, W. and Shen, Y. 2005. Phylogenetic relationships among Trichodinidae (Ciliophora: Peritricha) derived from the characteristic values of denticles. Acta Protozoologica, 44: 237-243.

Mhaisen, F. T. 2018. Index-catalogue of parasites and disease agents of fishes of Iraq. (Unpublished: mhaisenft@yahoo.co.uk).

Mitra, A. K. and Bandyopadhyay, P. K. 2009. Dipartiella kazubskisp. nov. (Ciliophora: Peritrichida), a new ectoparasitic trichodinid species from the gills of freshwater fishes in India. Protistology, 6(1):33-38.

Özer, A., Öztürk, T., Kornyychuk, Y. M. and Yurakhno, V. 2015. Trichodina gobii (Ciliophora: Trichodinidae) on whiting Merlangius merlangus with a checklist from Turkish and Russian coasts of the Black Sea. Acta Zoologica Academiae Scientiarum Hungaricae, 61 (2): 119-134.

Raabe, Z. 1959. Urceolariidae of gills of Gobiidae and Cottidae from Baltic Sea. Acta Parasitologica Polonica, 7: 441-452.

Saha, M. and Bandyopadhyay, P. K. 2017. Occurrence of two new species of the genus Dipartiella (Raabe, 1959) Stein 1961 (Ciliophora: Trichodinidae) isolated for the first time from ornamental fish. Journal of Parasitic Diseases, 41(4): 940-946.

Shuaib, M.E. and Osman, H.A. 2015. Survey of internal protozoan parasites on freshwater fish Oreochromis niloticus in White Nile in Sudan. Direct Research Journal of Agriculture and Food Science, 3(3): 62-69.

Van As, J. G. and Basson, L. 1989. A further contribution to the taxonomy of the Trichodinidae (Ciliophora: Pertrichia) and a review of the taxonomic status of some fish ectoparasitic trichodinids. Systematic Parasitology, 14(3): 157-179.

Van As, J. G. and Basson, L. 1992. Trichodinid ectoparasites (Ciliophora: Trichodinidae) of freshwater fishes of the Zambesi River System, with a reappraisal of host specificity. Systematic Parasitology, 22: 81-99. 
Bull. Iraq nat. Hist. Mus.

December, (2018) 15 (2): 139-144

تسجيل نو عين من الجنس Dipartiella (Raabe, 1959) Stein, 1961 (شعبة حاملات الأهداب: عائلة تر ايكودينيدي) لأول مرة في العر اق من غلاصنم سمكة الكارب الإعتيادي Cyprinus carpio

كفاح ناصر عبد الأمير وفاطمة خلف عطوان

قسم علوم الحياة، كلية التربية للعلوم الصرفةتـ إبن الهيثم، جامعة بغداد، بغداد، العراق

تاريخ القبول: 2018/05/21

تاريخ الاستلام: 2018/04/23

\section{الخلاصة}

أظهر فحص غلاصم سمكة الكارب الإعتيادي Cyprinus Carpio وجود نوعين من Dipartiella (Raabe, 1959) Stein, يعودان لجنس 1961 Trichodinidae عائلة 196 و هما D. kazubski D. indiana لأول مرة في العراق من منطقة الكريعات على نهر

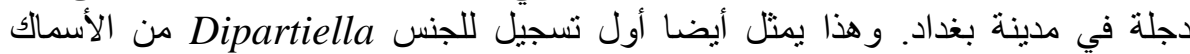
العر اقية. تم إعطاء مو اصفات وقياسات كلا الطفيليين فضلا عن الرسوم التوضيحية لهما. 